Hofbauer G., Klimontowicz M., \& Nocoń A. (2016). Basel III Equity Requirements and a Contemporary Rating Approach. Copernican Journal of Finance \& Accounting, 5(1), 91-105. http://dx.doi. org/10.12775/CJFA.2016.005

\author{
Günter Hofbauer*
}

Technische Hochschule Ingolstadt, Germany

\author{
MONIKa KLIMONTOWicz ${ }^{* *}$ \\ University of Economics in Katowice, Poland
}

\author{
Aleksandra Nocon ${ }^{* * *}$ \\ University of Economics in Katowice, Poland
}

\title{
BASEL III EQUITY REQUIREMENTS AND A CONTEMPORARY RATING APPROACH
}

Keywords: Basel III, equity regulation, rating classes, risk, sustainability.

\section{J E L Classification: G30, M10.}

Abstract: The new equity regulations of Basel III are more restrictive. Therefore the research objective of this article is to show the impact of equity regulations and to provide a proposal for professional preparation for the rating procedure for credit seeking companies. The research method applied is to give an overview of the relevant equity

Date of submission: May 18, 2016; date of acceptance: June 10, 2016.

* Contact information: guenter.hofbauer@thi.de, Technische Hochschule Ingolstadt, Business School, Esplanade 10, D-85049 Ingolstadt/Germany, phone: +4984193483590.

** Contact information: mklimontowicz@ue.katowice.pl, University of Economics in Katowice, Faculty of Finance and Insurance, Department of Banking and Financial Market, ul. 1 Maja 50, 40-287 Katowice, Poland, phone: +48321577421.

*** Contact information: aleksandra.nocon@ue.katowice.pl, University of Economics in Katowice, Faculty of Finance and Insurance, Department of Banking and Financial Market, ul. 1 Maja 50, 40-287 Katowice, Poland, phone: +48321577421. 
regulations of Basel III. From this research, we can derive that risk is the most important issue to be considered. In consequence, the outcome is a proposal for a contemporary rating approach for companies, containing an appropriate way how to control risk and perform in an excellent way.

We can conclude, that the new equity regulations will not only have an impact on banks, but also on credit taking companies. Especially small and medium-sized companies will be affected. Furthermore in future banks intend to get an exhaustive insight into companies. The risks identified in the business will serve as a measure to calculate a risk adequate interest rate, depending on the rating class. Therefore it won't be sufficient anymore to use only backward looking statements from the balance sheet or profit and loss statement.

In this article we propose an evidence based approach for executing a professional and sustainable rating. Supporting this, we provide six dimensions for a contemporary rating approach.

\section{INTRODUCTION}

The collapse of Lehman Brothers and the subsequent events on global financial markets has revealed that it is necessary to reform the financial system, especially banking sector. The first outline of the reforms was presented at a meeting of G20 leaders in April 2009 in London. In response to the global financial crisis, an important role was assigned to the Basel Committee on Banking Supervision, which within two years has developed a set of new rules regulating banking activity. These new rules and regulations will not only have an impact on banks but also on credit seeking companies, especially small and mediumsized companies. In this article, we provide an overview of the relevant equity regulations for banks. Therefore, the banks have to be more careful to accept risk in their business. In order to avoid risk, the banks will have a closer look on the business of the credit-seeking companies and the risk involved in these companies. Depending on the risk and the corresponding rating class the decision about the creditworthiness and the extent of the interest rate will be done. If credit seeking companies have excellent performance indicators, they will get credit under good conditions, otherwise, they won't.

\section{RESEARCH METHODOLOGY}

The research methodology is twofold. First we do literature research, especially in the Basel framework, paying particular attention to the equity requirements. Second we do empirical research and present the impact of Basel III regulation on bank's selected indicators as tier 1 ratios, the share of equity capital 
in total assets, and the debt-to-equity ratio from Poland and Germany. These figures are displayed in comparison before Basel III and nowadays, during the implementation of Basel III.

\section{BASEL III IN THE CONTEXT OF EQUITY REGULATIONS AND REQUIREMENTS}

In December 2010 the Basel Committee has published two documents, which significantly changed the rules of the banking institutions functioning after the financial crisis of 2007-2008:

- Basel III: A global regulatory framework for more resilient banks and banking systems,

- Basel III: International framework for liquidity risk measurement, standards and monitoring.

These documents constitute a set of regulations known as Basel III, which complement the earlier recommendations of the Basel Committee - Basel I and Basel II (The New Basel Capital Accord).

Basel III distinguishes two categories of capital in banks: tier I and tier II. Thereby, Tier III capital - introduced in The New Basel Capital Accord, disappeared in Basel III (Iwanicz-Drozdowska 2012). Since the beginning of the Basel capital regulations, tier I capital had the task of absorbing losses incurred by a bank (BCBS, 1988). The higher the level of tier I capital in relation to the scale of its operations, the higher the ability to survive periods of instability. However, after the experience of the global financial crisis, the Basel Committee has proposed tightening the rules for qualifying specific positions as core capital, to fully meet the requirements associated with the ability to cover losses. The amount of the capital adequacy ratio was left at the current level of $8 \%$. Nevertheless, in Basel III there has been made the distinction of own funds in (Iwanicz-Drozdowska 2012, Nocoń 2016):

- tier I capital, described as going concern capital,

- tier II capital, described as gone concern capital.

This distinction between going and gone concern capital results from a situation, in which the individual categories of capital may be used to cover losses. In the case of tier I capital it is always possible, in the case of tier II capital - only during bankruptcy or liquidation of a bank.

According to Basel III, tier I capital consists of common equity tier I (CET1) and additional tier I capital. However, the main emphasis is on common equity tier I, which includes (Basel III 2010): 
- ordinary shares issued by a bank,

- the issue premium arising from the issuance of instruments classified as common equity tier I,

- retained profits and other accumulated profits and disclosed reserves.

The above capital has to be considered as equity capital, according to national accounting standards. At the same time, it cannot be regarded as a liability for the purposes of determining the state of insolvency on the basis of balance sheet data, and must be specifically extracted in the balance sheet of banking institution. In turn, among the components of tier II capital (supplementary funds) subordinated debt and reserves of general risk and surplus reserves for expected losses on the loan portfolio were qualified. These requirements are intended to prevent the assignment to own funds of such components, which are not adequately safe from the point of view of banks' capital adequacy (Kopiński 2008). A kind of 'failure' of hybrid instruments as a component of tier I, required a tightening of the equity criteria (Iwanicz-Drozdowska 2012).

In the existing regulations the relation between core and supplementary capital may amount to a maximum of $50 \%$. In turn, subordinated loans classified as tier II capital could provide no more than $25 \%$ of core capital. This meant that the capital adequacy ratio calculated for tier I could not be less than $4 \%$. Basel III has tightened existing recommendations, assigning a greater role of tier I capital. Banks should therefore maintain capital adequacy ratios at the following levels (Basel III 2010):

$$
\begin{gathered}
\text { Common Equity Tier I ratio (CET1) } \geq 4,5 \% \\
\text { Tier I Capital ratio } \geq 6 \% \\
\text { Capital Adequacy Ratio (Tier I + Tier II) } \geq 8 \%
\end{gathered}
$$

Despite the fact that the Basel Committee maintained the current level of capital adequacy ratio at a level of $8 \%$, but it also introduced two capital buffers:

- capital conservation buffer - which has protective character,

- countercyclical buffer - which has countercyclical character.

Their aim is to increase the security of banks and banking sector, increasing requirements for the level of adequacy ratio, taking into account common equity tier I. Capital conservation buffer refers to the level of capital protection at the level of individual bank (microeconomic approach), while the countercy- 
clical buffer - at the level of the banking sector of a country (macroeconomic approach).

The protective buffer applies to all banks, regardless of jurisdiction, aiming to increase their resilience, expanding the capacity to absorb losses, as well as reducing the possibility of lowering the capital adequacy ratio below $8 \%$. The buffer limits possibilities of disposal of generated capital by banks through restrictions of paid dividends, buying its own shares or paying bonuses. Capital conservation buffer will appear in 2016 at a level of $0.625 \%$, in the following year it will increase to $1.25 \%$, after that to $1.875 \%$, and from the beginning of 2019 it will amount to $2.5 \%$ (Basel III 2010).

The countercyclical buffer is an essential macro-prudential tool of the whole package of regulation. It has been addicted on the development of lending in a country. Its aim is to correct the growth rate of lending (cooling). It was added to the protective buffer. This buffer requires to maintain additional common equity tier I in the range of 0 to $2.5 \%$ of risk weighted assets, depending on the assessment of the financial safety net institutions about the possibility of generating excessive systemic risk. The level of the buffer will vary with the level of protection buffer - in 2016 it will be at a maximum level of $0.625 \%$, gradually increasing the maximum value to $2.5 \%$. To determine the appropriate level of the countercyclical buffer, supervisory authorities should monitor banks' lending activities and other indicators related to systemic risk. This is to determine whether credit growth is not excessive and does not cause an increase of systemic risk (Basel III 2010).

Figure 1. Changing equity structure from Basel I and II to Basel III

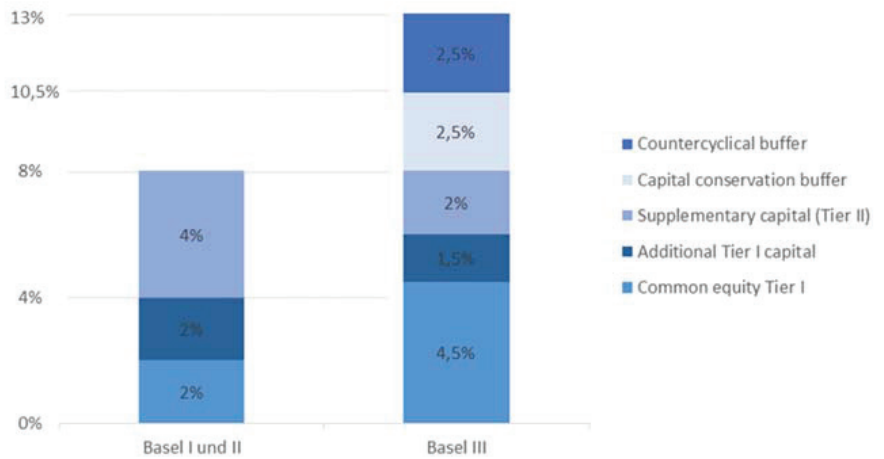


Basel III has caused a real increase in capital charges for banks (see figure 1). The level of capital adequacy ratio is still equal to $8 \%$, however the sum of minimum tier I ratio, minimum tier II ratio and capital conservation buffer was set at a level of $10.5 \%$. Moreover, taking into account countercyclical buffer, equity requirements for banks increased to $13 \%$.

\section{THE COMPARISON OF THE BASEL III IMPACT ON POLISH AND GERMAN BANK INDICATORS}

The Basel III framework focuses on capital as a guarantee of bank's safety and its ability to absorb any possible risk that might happen. The comparison between the level of bank's core capital and total risk-weighted assets is measured by Tier 1 capital ratio. This ratio shows the financial strength of a bank. During the last decade the level of this ratio has been systematically increasing in both German and Polish banking market. The comparison between Polish and German banks show that the capital base in Poland was stronger before the Basel accords implementation (see Figure 2). Today both countries fulfil the Basel requirements but the share of equity capital in total assets is still at the higher level in Poland (see Figure 3).

Figure 2. Tier 1 ratio in Germany and Poland (EBC, DB Research)

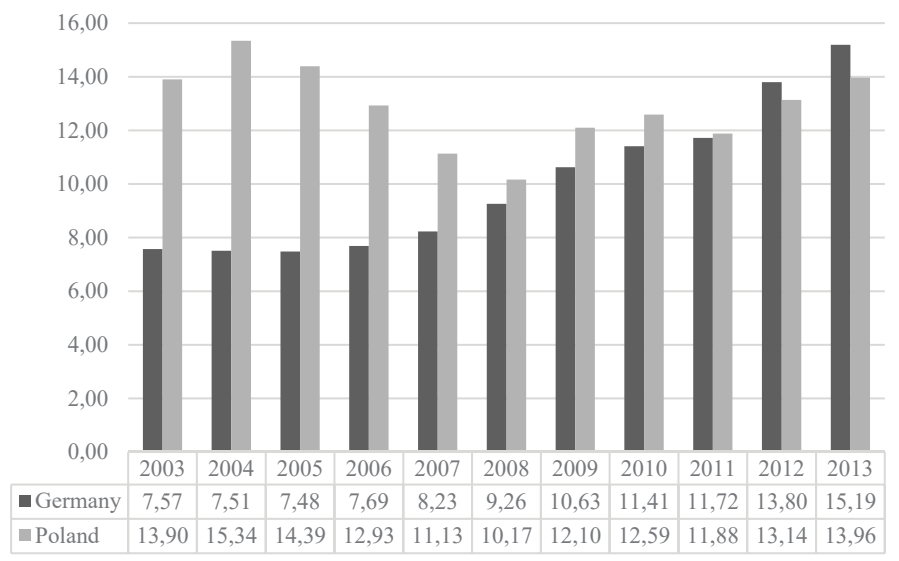


Figure 3. Equity capital in \% of total assets (Capital \& Reserves/Total assets*100) in Germany and Poland (EBC, DB Research)

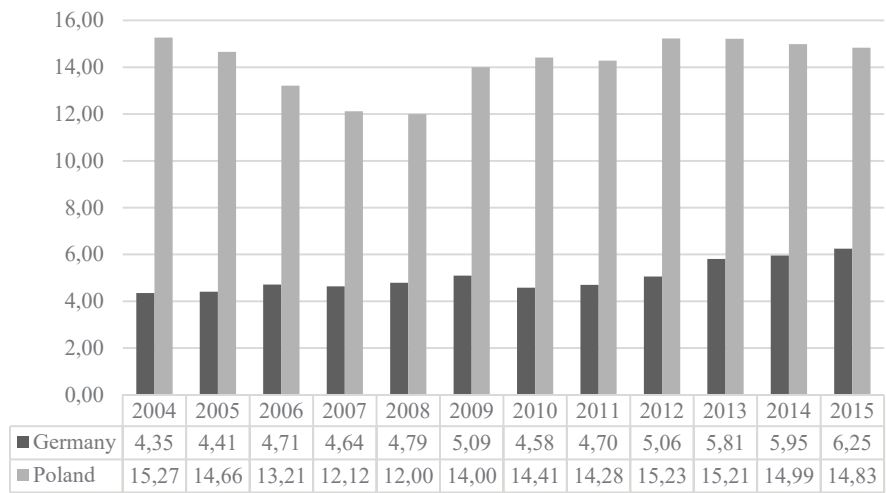

S o u r c e : own work based on: ECB and DB Research data.

Fulfilling Basel III requirements has already influenced banks' market policy and has changed the way of financing banks' operations. The analysis of debt-to-equity shows that during the last 10 years the share of debt defined as a specific subset of liabilities has changed. Since 2008 the level of ratio is decreasing but still the outstanding debt is over three times larger than equity (see Figure 4).

Figure 4. Debt-to-equity in Germany and Poland (EBC, DB Research)

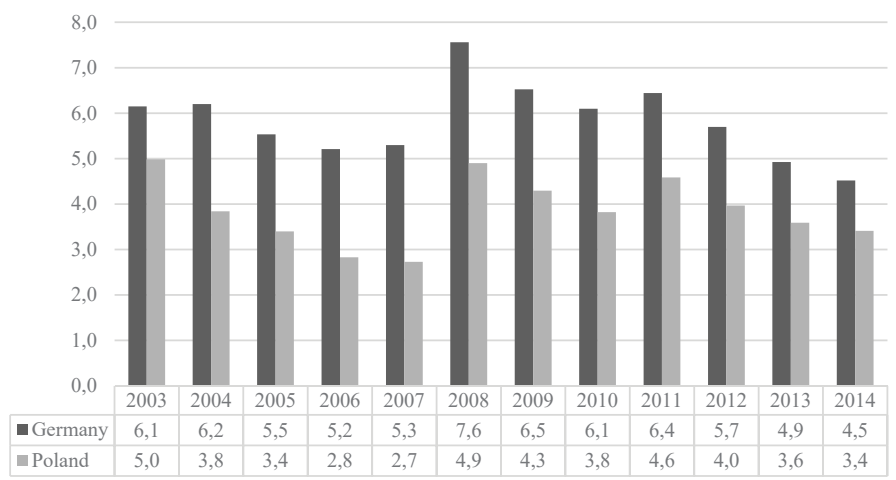

S o u r c e : own work based on: ECB and DB Research data. 
As for banks the own funds are preferable as a denominator to avoid stock market fluctuations meeting capital requirements will require changing the credit policy and bank's rating approach.

\section{A CONTEMPORARY RATING APPROACH}

From our research and analysis we can summarize that the equity regulations become more restrictive and in coincidence with that, banks will be more careful in assessing the creditworthiness. From empirical research we can see, that selected figures are changing over time and that there are differences between Germany and Poland. From figure 3 and 4 we can deduct that there is still a need for equity, in Germany more than in Poland. Companies seeking for credits have to be well prepared for the assessment of banks and the rating process. In this chapter we make a proposal for a contemporary rating approach.

The rating of a company depends very strongly on the future perspectives and the ability to generate profits. The basis of value creating operations is the successful management of the relationships to customers and suppliers. Within the framework of value orientation and sustainability companies have to focus on the relationship management. This task is executed particularly in the marketing and sales department. The financial figures from the financial report and the balance sheet do not have a satisfactory indication, because these are backward oriented and fixed to the reporting date. Hence it is insufficient to use only these figures for credit rating. In order to include also the potential of the future, the relationships to customers and suppliers as well have to be considered for the evaluation of the creditworthiness. The main variables of the relationship management will be shown in this article, to make them available for the credit check for the banks and for adequate preparation of the companies.

\section{QUESTIONS ABOUT THE COMPANY}

One of the most important challenges in managing successful companies is to reduce risk by creating sustainable and value oriented relationship management. In doing this the value of the company will increase and the credit rating will be influenced positively. A prior task for the management is to care about a transparent reporting of the business related situation and for an open and straightforward communication to the bank as a professional basis for the credit rating. In former times it might have been sufficient to show the balance 
sheet and the profit and loss statement. But in times of financial crisis and Basel III this is not enough, because these records are backward oriented and fixed (sometimes estimated) with reference to a due date, mostly end of year. Rather than that, it is important to demonstrate the preparedness for future challenges and indicate the sustainability and profitability of the business. Table 1 shows specific questions about your company, which have to be answered in a credit rating.

Table 1. Questions about your company

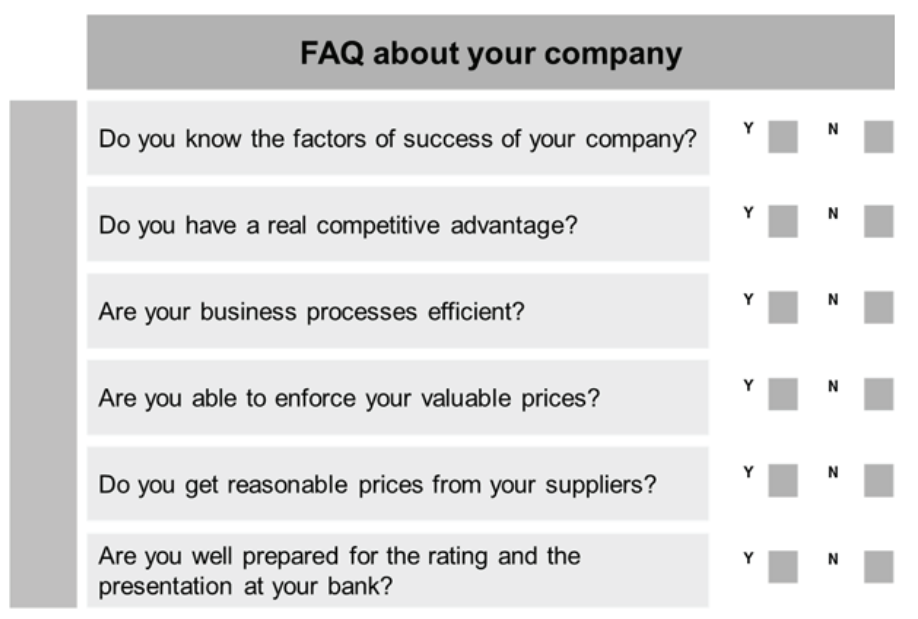

S o u r c e : own work.

\section{RATING CLASSES AS AN OUTCOME OF EVALUATION}

Banks are obligated to observe bank lending basic rules. Following the Basel III accord the banks have to prove even more strictly the creditworthiness of a company. Because of the financial crisis - the effects are still noticeable - the banks are particularly careful. Subsequently it will be necessary for all companies to substantiate the creditworthiness not only by the means of financial rating but also by structural rating.

Here we see an imperative need for action, especially for small and medium sized companies, to be prepared for these new rules of rating and prerequisites for credit issueing. Well managed companies will get better credit conditions and will be charged with less cost of credit capital. The most important 
issue in achieving profitability and sustainability is the overall principle of value creation. The relationships to customers as well as to suppliers have a distinguished significance, because those have an outstanding influence on the value creation.

The better the companies are valuated with respect to profitability and sustainability, the better the rating and concurrently the better the credit conditions will be. Table 2 (source: websites of companies) shows the various rating classes and their meanings.

Table 2. Rating classes

\begin{tabular}{|c|c|c|c|c|c|c|c|c|}
\hline \multicolumn{2}{|c|}{ Moody's } & \multicolumn{2}{|c|}{ Sep } & \multicolumn{2}{|c|}{ Fitch } & \multirow[t]{2}{*}{ DBRS } & \multirow[t]{2}{*}{ Code } & \multirow[t]{2}{*}{ Description } \\
\hline Long Term & Short Term & Long Term & Short Term & Long Term & Short Term & & & \\
\hline Aal & \multirow{3}{*}{ P-1 } & AAt & A-1+ & Aat & A1+ & Aathigh & High grade & $\begin{array}{l}\text { Very strong capacity to meet financial } \\
\text { commitments. }\end{array}$ \\
\hline A1 & & At & A-1 & At & A1 & Ahigh & \multirow{3}{*}{ Upper Medium grade } & \multirow{3}{*}{$\begin{array}{l}\text { Strong capacity to meet financial } \\
\text { commitments, but somewhat susceptible to } \\
\text { adverse economic conditions and changes in } \\
\text { circumstances. }\end{array}$} \\
\hline A2 & & $\mathbf{A}$ & A.1 & A & 21 & A & & \\
\hline $\mathbf{A 3}$ & P-2 & A. & A-2 & A. & A2 & Alow & & \\
\hline Baa3 & p-3 & в88. & A-3 & 888- & A3 & BeBlow & Lower Medium grade & $\begin{array}{c}\text { Considered lowest investment grade by } \\
\text { market participants. }\end{array}$ \\
\hline Ba1 & \multirow{8}{*}{ Not Prime } & Ba. & \multirow{5}{*}{$\mathbf{8}$} & ae. & \multirow{5}{*}{ B } & eahigh & \multirow{3}{*}{$\begin{array}{l}\text { Non } \\
\text { Investmentgrade } \\
\text { speculative }\end{array}$} & $\begin{array}{l}\text { Considered highest speculative grade by } \\
\text { market participants. }\end{array}$ \\
\hline Ba2 & & BB & & $\mathbf{B B}$ & & $\mathbf{8 B}$ & & Less vulnerable in the near-term but faces \\
\hline Ba3 & & 8e- & & Be- & & Below & & $\begin{array}{l}\text { major ongoing uncertainties to adverse } \\
\text { business, financial and economic conditions. }\end{array}$ \\
\hline B1 & & 8. & & B+ & & Bhigh & & More vulnerable to adverse business, \\
\hline 82 & & B & & B & & B & Highly Speculative & $\begin{array}{l}\text { financial and economic conditions but } \\
\text {. }\end{array}$ \\
\hline c & & $\mathrm{ccc}$ - & c & ccc & c & c & $\begin{array}{l}\text { In default with little } \\
\text { prospect for recovery }\end{array}$ & $\begin{array}{l}\text { Currently highly vulnerable obligations and } \\
\text { other defined circumstances. }\end{array}$ \\
\hline$\frac{1}{1}$ & & \multirow[b]{2}{*}{ D } & \multirow[b]{2}{*}{ I } & DDD & \multirow[b]{2}{*}{ I } & & \multirow[b]{2}{*}{ In default } & \multirow[b]{2}{*}{ Payment defautt on financial commitments. } \\
\hline$\frac{1}{1}$ & & & & DD & & D & & \\
\hline
\end{tabular}

S o u r c e : websites of companies.

\section{PROBLEM FORMULATION}

A strong dependency of a company on customers and suppliers is a severe problem for the rating. Deducted from these relationships we can identify essential factors influencing the creditworthiness. In order to calculate the contained business risk, the banks have to look on these relationships very closely. If a company has an unbalanced dependency, either on the customer or on the supplier side, this may imply a severe crisis. The company can face a loss of a key account customer or a drop out of an important supplier. In any comparable case there will be a crisis with an impact on the rating. This impact will be displayed by a continuous rating, if banks wait until this crisis will be visible on the financial statements, it will be too late. 
The most important issues, which will give a comprehensive indication are (basis: own research):

- excellence and ability of the management, process orientation, business model

- potential markets, future prospects to create value, competitive position,

- sales volume and earnings, profitability, strategic position

- stable relationships, customer satisfaction

- innovation, modern product portfolio, competitiveness

- controlling, quality and availability of relevant information,

Taking this context into account, we strongly recommend to use those indicators and measures, which result directly from the business and which are appropriate to display the risk included in the business model and the impact on the success. Subsequently we have to consider these variables of success.

\section{PROBLEM SOLVING BY EVALUATING WITH STRUCTURAL RATING}

The awareness of the valuation and usefulness of the success factors of a company gives more significance to this issue in management. Marketing and sales contribute dominantly to the success and can help to manage risk arising from dependencies. There are promising potentials in the area of markets. Coming from these indicators, we defined six different areas (left side of table 3), which can contribute positively to the credit rating, if they are managed well. The outcome of the different dimensions are displayed on the right side of table 3 . We can summarize, that all these issues are about the indicators, we pointed out in the problem formulation.

The task for the companies is to disclose all these indicators in a comprehensible and documented way for the banks. The task for the banks is to evaluate and examine these indicators. This examination should not be a matter of trust and believe. In fact it should be a matter of business knowledge, market intelligence and management experience. 
Table 3. System of rating dimensions (Hofbauer, Bergmann 2013, 340)

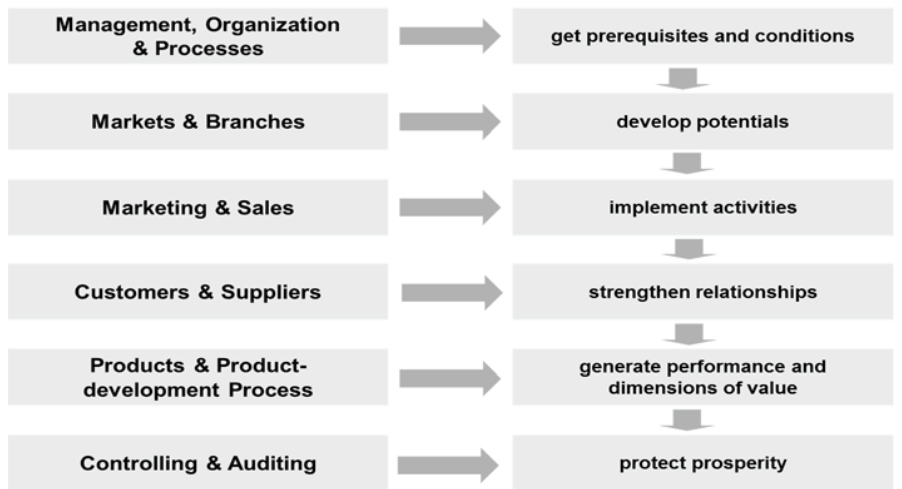

S o u r c e : Hofbauer, Bergmann 2013.

For example the assessment of future prospects should include the whole business environment with short term expectations in business as well as long term perspectives within the relevant industry. The individual situation of the company is strongly related to the market position. For the execution of a professional rating all relevant indicators have to be scrutinized and subsequently evaluated due to the rating classes (table 2).

Table 4. Indicators for future prospects

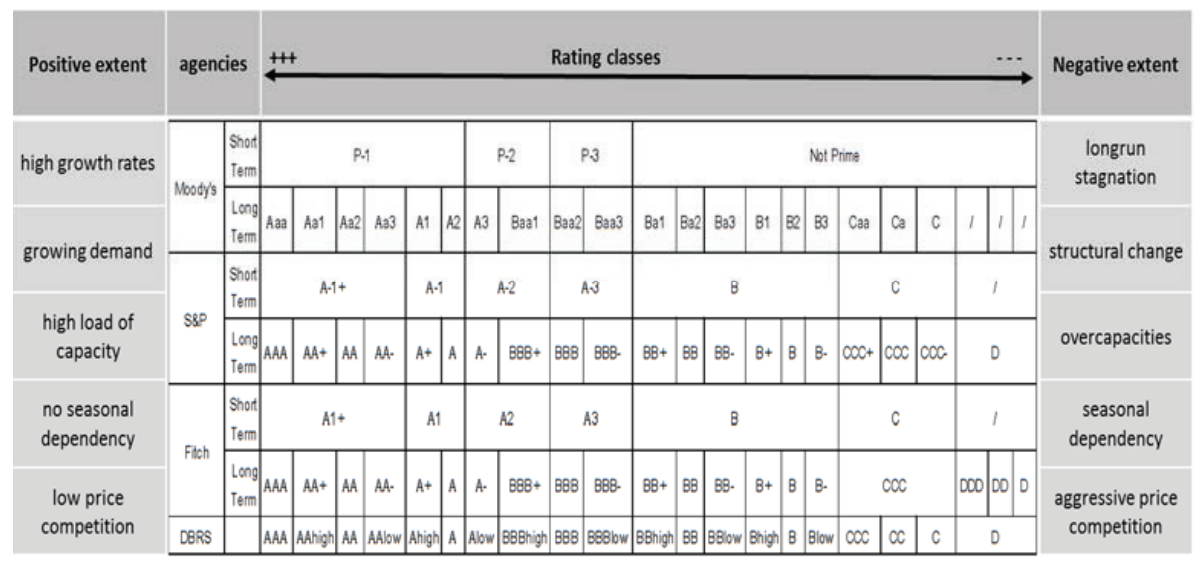

S o u r c e : own work. 
These indicators for future prospects can also be influenced by the competitive position of a company. The consequent practice is to evaluate these issues as well. The indicators of success and future prospects could be: market position as market share, market position, price enforcement and cost of production, product quality and product portfolio, production sites and legal protection. The assessment is shown in table 5.

Table 5. Indicators for competitive position

\begin{tabular}{|c|c|c|c|c|c|c|c|c|c|c|c|c|c|c|c|c|c|c|c|c|c|c|c|}
\hline Positive extent & \multicolumn{2}{|c|}{ agencies } & \multicolumn{8}{|c|}{+} & \multicolumn{12}{|c|}{ Rating classes } & \multirow{2}{*}{$\begin{array}{c}\text { Negative extent } \\
\begin{array}{c}\text { low market } \\
\text { position }\end{array}\end{array}$} \\
\hline $\begin{array}{l}\text { Important market } \\
\text { position }\end{array}$ & \multirow{2}{*}{ Moody's } & shot & \multicolumn{6}{|c|}{ P.1 } & \multicolumn{2}{|c|}{ P.2 } & \multicolumn{2}{|c|}{ P3 } & \multicolumn{10}{|c|}{ Not Prime } & \\
\hline $\begin{array}{l}\text { positive trend for } \\
\text { sales and profit }\end{array}$ & & $\begin{array}{l}\text { Long } \\
\text { Term }\end{array}$ & Aas & Aa1 & Aa2 & $A 33$ & A1 & A2 & A3 & Baa1 & Baz2 & Ba3 & Ba1 & 832 & Ba3 & $\begin{array}{ll}B 1 & B 2\end{array}$ & \begin{tabular}{l|l|}
$B 2$ & 83
\end{tabular} & $\mathrm{Cas}$ & ca & c & 111 & 1 & \multirow{3}{*}{$\begin{array}{c}\begin{array}{c}\text { downturn in } \\
\text { sales and profit }\end{array} \\
\begin{array}{c}\text { no competitive } \\
\text { advantage }\end{array} \\
\begin{array}{c}\text { outdated } \\
\text { product program }\end{array}\end{array}$} \\
\hline $\begin{array}{l}\text { excellent product } \\
\text { quality }\end{array}$ & \multirow[b]{2}{*}{$S S P$} & Shot & \multicolumn{4}{|c|}{ A. $1+$} & A- 1 & & \multicolumn{2}{|c|}{ A.2 } & \multicolumn{2}{|c|}{ A3 } & \multicolumn{5}{|c|}{$B$} & \multicolumn{3}{|c|}{ c } & \multicolumn{2}{|l|}{1} & \\
\hline $\begin{array}{l}\text { balanced and } \\
\text { modern portfolio } \\
\text { of products and }\end{array}$ & & $\begin{array}{l}\text { Long } \\
\text { Term }\end{array}$ & AAA & $A A+$ & AA & AA. & $\mathrm{A}^{+}$ & A & A. & 888+ & B8B & B88- & $88+$ & 88 & B8. & $B+B$ & \begin{tabular}{l|l|l}
8 & 8.
\end{tabular} & $000+$ & $\cos$ & $c 00$ & D & & \\
\hline $\begin{array}{l}\text { location with } \\
\text { advantages }\end{array}$ & \multirow{2}{*}{ Fitch } & $\begin{array}{l}\text { Shot } \\
\text { Term }\end{array}$ & \multicolumn{4}{|c|}{ A1+ } & A1 & & \multicolumn{2}{|c|}{ A2 } & \multicolumn{2}{|c|}{$A^{3}$} & \multicolumn{5}{|c|}{ B } & \multicolumn{3}{|c|}{ c } & \multicolumn{2}{|l|}{1} & \multirow{2}{*}{$\begin{array}{l}\text { disadvantages } \\
\text { due to location }\end{array}$} \\
\hline $\begin{array}{l}\text { relative to } \\
\text { competition }\end{array}$ & & $\begin{array}{l}\text { Long } \\
\text { Term }\end{array}$ & AAA & $A A+$ & AA & AA. & $\mathrm{A}^{+}$ & A & A. & 888+ & BBB & BBB- & $68+$ & 88 & BB. & $B+B$ & $\begin{array}{ll}B & 8 .\end{array}$ & & $c c c$ & & $000 \mid 00$ & 0 & \\
\hline $\begin{array}{l}\text { extensive patent } \\
\text { protection }\end{array}$ & DBRS & & $A A A$ & Ahhigh & AA & AAlow & Ahigh & A & Alow & B8Bhight & $88 B$ & Be8bw & Bohight & 88 & BBiow: & Bhigh $B$ & B Blow & $\infty \infty$ & $\infty$ & c & D & & $\begin{array}{l}\text { no patent } \\
\text { protection }\end{array}$ \\
\hline
\end{tabular}

S o u r c e : own work.

\section{CONCLUSION}

In this article we have analysed and outlined the Basel III equity regulations and measures. An important indicator is the risk taken by a bank as a creditor. The degree of risk influences the amount of equity. The higher the risk, the higher the equity, which has to be backed in a bank in order to protect the single bank as well as the whole banking sector from the next crisis. A well performing banking sector is an important prerequisite for an ongoing economy. Economy has to be provided with money. In the part of the empirical research, we have analysed selected financial figures. These figures show, that there is a difference between Germany and Poland, that there is a difference in time and that there is still need for credit for companies. This supply of credit has to be fulfilled by banks in a responsible way, taking the risk positions of the debtors 
and their business into account. The more risk a bank is willing to accept, the more equity has to be backed.

Banks have to be careful in giving out loans and they have to obey security measures. In consequence, banks are not willing to give credits to companies with high risk positions. Rather they prefer to give credits to companies with a low risk position, even with better conditions for the debtors. To assess and evaluate the risk position, the professionally executed rating procedure and the rating grade will gain more and more importance.

Particularly in the rating of the creditworthiness according to the new requirements, the assessment beyond the balance sheet will become more and more important. The basis for a good or even excellent rating grade are the potentials arising from excellent managing practices. These are the prerequisites for value creation and subsequently profitable and sustainable outcomes. By managing the introduced rating dimensions, these potentials can be identified and deployed. Risks and challenges should be evaluated as well.

By the use of a professional preparation of the credit rating, companies will be able to:

- identify levers and measures for a profitable adjustment of the business,

- communicate a convincing business concept to the bank,

- reduce the apparent risk and get better credit conditions.

The perfect matching and combination of the factors of success leads to a perfect and satisfying result of the credit rating. In the future the presented rating dimensions will be even more important as they are actually considered. Well performing companies will get better ratings and as a consequence better credit terms.

\section{UI REFERENCES}

Basel Committee on Banking Supervision (1988). International Convergence of Capital Measurement and Capital Standards. July.

Basel III (2010). A Global Regulatory Framework for More Resilient Banks and Banking Systems. Basel Committee on Banking Supervision. December 2010 (modified version: June 2011).

Hofbauer, G. (2008). Bankenkrise, Finanzkrise, Unternehmenskrise? Durch Strukturrating die Zukunftsfähigkeit verbessern. In: Going Public, Juni 2008, pp. 68-69.

Hofbauer, G. (2009). Bankenfestes Rating durch erfolgreiche Kunden- und Lieferantenbeziehungen. So decken Sie Risiken auf und steigern den Unternehmenswert, in: NWB Betriebswirtschaftliche Beratung, ISSN 1868-2979, Heft 5, pp. 150-155, Bochum. 
Hofbauer, G., \& Bergmann, S. (2008). Bankenfestes Rating im Marketing und Vertrieb. Leitfaden zur systematischen Ratingvorbereitung, in: BBB BeraterBrief Betriebswirtschaft, ISSN 1861-308X, Heft 5, pp. 371-375, Bochum.

Hofbauer, G., \& Bergmann S. (2008). Optimales Rating für KMU, So überzeugen Sie Ihre Bank, Erlangen 2008.

Hofbauer, G., \& Bergmann S. (2013). Professionelles Controlling in Marketing und Vertrieb, Ein integrierter Ansatz, Mit Kennzahlen und Checklisten, Erlangen 2013.

Hofbauer, G., \& Hellwig C. (2012). Professionelles Vertriebsmanagement, Der prozessorientierte Ansatz aus Anbieter- und Beschaffersicht, 3. Auflage, Erlangen 2012.

Hofmann, G. (editor) (2015). Basel III, Risikomanagement und neue Bankaufsicht. Frankfurt School Verlag, Frankfurt.

Iwanicz-Drozdowska, M. (2012). Banking risk management. Poltext, Warsaw.

Kopiński, A. (2008). Bank's financial analysis. PWE, Warsaw.

Meissner, G. (2014). Correlation Risk Modelling and management: An Applied Guide including the Basel III Correlation Framework. Wiley, Weinheim.

Nocoń, A. (2016). The response system of modern central banks on banking system instability. Difin, Warsaw.

Sander, C.-D. (2014). Mit Kreditgebern auf Augenhöhe verhandeln. Betriebswirtschaftliche Beratung Kompakt, Herne.

Trueck, S., \& Rachev, S. (2008). Rating based Modeling of Credit Risk: Theory and Application of Migration Matrices. Academic Press Advanced Finance, Amsterdam. 